\title{
Persepsi Dosen Tetap Vokasi UI Terhadap Proses Berbagi Pengetahuan Melalui Communities of Practice (CoP) Dyah Safitri ${ }^{1}$ \\ ${ }^{1}$ Laboratorium Manajemen Informasi dan Dokumen, Program Vokasi UI, dyajeng_safitri@yahoo.com
}

\begin{abstract}
Abstrak
Hasil penelitian mengenai persepsi dosen tetap Program Vokasi UI terhadap proses berbagi pengetahuan melalui Communities of Practices (CoP). Ada tiga hipotesis riset yang dibuktikan yaitu (1) Persepsi dosen tetap terhadap berbagi pengetahuan adalah positif (2) Persepsi dosen tetap terhadap $\mathrm{CoP}$ positif dan (3) Persepsi dosen tetap terhadap dokumen sebagai sarana berbagi pengetahuan lewat CoP. Hasil dari survei membuktikan bahwa persepsi dosen tetap Program Vokasi UI terhadap tiga hipotesis riset tersebut adalah positif. Sehingga CoP dapat menjadi alternatif penciptaan pengetahuan di antara dosen tetap Program Vokasi UI. Keterbatasan penelitian adalah hanya untuk organisasi tersebut dan hasilnya dapat berbeda apabila yang diteliti adalah organisasi yang memiliki kompleksitas yang berbeda
\end{abstract}

Kata Kunci : Berbagi pengetahuan, CoP, dosen tetap program Vokasi UI, tacit knowledge, pengetahuan eksplisit

\begin{abstract}
The results of research on the perception of permanent lecturers vocational program UI for the sharing of knowledge through Communities of Practices (CoP). There are three research hypotheses were proved, namely (1) Perception of tenured faculty to share knowledge is positive (2) The perception of permanent lecturers to positively $\mathrm{CoP}$ and (3) Perceptions of permanent lecturers of the document as a means of sharing knowledge through CoP. Results of the survey prove that the perception of permanent lecturers UI vocational program to three research hypothesis is positive. So that the $\mathrm{CoP}$ can be an alternative to the creation of knowledge among tenured faculty vocational program UI. Limitations of the study is only for the organization and the results can be different if the study is an organization that has a different complexity
\end{abstract}

Keywords: Sharing knowledge, CoP, tenured faculty Vocational UI program, tacit knowledge, explicit knowledge

\section{PENDAHULUAN}

\section{Latar Belakang}

Berbagi pengetahuan adalah proses penting di dalam sebuah organisasi dalam mengelola dan menciptakan pengetahuan baru. Pengetahuan yang dimiliki oleh setiap individu dalam sebuah organisasi menjadi aset terbesar yang dapat dimanfaatkan untuk kemajuan organisasi. Ketika pengetahuan dapat dikelola dan dimanfaatkan dengan maksimal oleh organisasi, organisasi tersebut dapat maju dan bergerak lebih cepat. Pada organisasi baru seperti Program Vokasi UI, sangat penting untuk mengelola pengetahuan sejak dini agar pengetahuan dapat bermanfaat bagi pengembangan organisasi.

Dalam mengalirkan pengetahuan tersebut eksplisit maupun tacit-, organisasi membutuhkan proses berbagi pengetahuan (knowledge sharing) di antara anggota organisasi. Model penciptaan pengetahuan 
Nonaka dan Takeuchi (1995) memperlihatkan bahwa interaksi antara pengetahuan tacit dan eksplisit dapat terjadi di tingkatan individu, kelompok, organisasi, bahkan antar organisasi sehingga dapat dikembangkan berkelanjutan dalam setting sosial apapun. Nonaka dan Takeuchi (1995) juga memperlihatkan bahwa pengetahuan tacit lebih bersifat pribadi, punya konteks khusus, dan sulit dikomunikasikan maupun dibuat formal. Sedangkan pengetahuan eksplisit sebaliknya karena sifatnya lebih umum dan lebih mudah dialirkan.

Salah satu cara efektif untuk mengalirkan lewat proses berbagi pengetahuan adalah melalui $\mathrm{CoP}$ (communities of practice). Wenger (1999) mendefinisikan CoP sebagai sebuah kelompok orang yang peduli, berselera terhadap satu topik dan dengan pengetahuannya akan berinteraksi dengan yang lain . CoP menciptakan lingkungan yang ramah bagi individu dengan minat dan masalah yang sama untuk saling memindahkan pengetahuan dan menciptakan pengetahuan baru. Bagi organisasi, akuisisi pengetahuan melalui $\mathrm{CoP}$ memberi manfaat besar karena proses berbagi pengetahuan akan selalu sesuai dengan konteks dimana pengetahuan tersebut diterima dan dikembangkan.

Ada tiga karakteristik CoP (Wenger, 1999) yaitu keterlibatan bersama atau interaksi antar semua anggota, memberi makna pada tujuan dan prioritas, dan penggunaan bersama berupa cerita, metode, alat, dan teori-teori yang digunakan. Wenger, McDermott, dan Snyder (2002) melihat CoP sebagai sekumpulan orang yang berbagi perhatian terhadap serangkaian masalah ataupun hasrat pada topik tertentu yang membutuhkan pengetahuan dan keahlian interaktif. Paquette (2008) melihat bahwa kemampuan CoP menciptakan lingkungan yang ramah bagi individu dengan ketertarikan yang sama untuk berdiskusi dalam memindahkan pengetahuan dan menciptakan pengetahuan baru. Praktisi dengan pengalaman pekerjaan yang serupa dapat memicu komunitas ini dan berbagi pengetahuan dan pengalaman akan muncul dengan mudah. Aliran pengetahuan haruslah secara efisien dapat diakses oleh sesama anggota komunitas. Pan dan Leidner (2003) berpendapat bahwa organisasi perlu menyediakan beragam kanal komunikasi untuk mendukung kebutuhan berbagi pengetahuan. Batas $\mathrm{CoP}$ adalah dinamis sehingga ketika komunitas lain ingin berbagi pengetahuan melalui konteks, bahasa, dan budaya berbeda maka $\mathrm{CoP}$ dapat memotivasi anggota dari komunitas lain.

Pada prakteknya, CoP dapat mempermudah individu melakukan kontak dengan individu yang lain dengan minat dan keahlian serupa. Bentuknya dapat berupa berbagi sumber daya fisik maupun sumberdaya yang tidak terhitung seperti pertemuan tatap muka (face to face meeting). Selain itu, inisiatif $\mathrm{CoP}$ secara struktural juga akan mendorong berbagi pengetahuan dalam struktur organisasi misalnya menggunakan teknologi informasi dalam penyediaan sumber daya yang dibutuhkan dalam berbagi pengetahuan. Dalam organisasi, bentuk CoP dapat berupa forum diskusi yang membahas tema-tema 
tertentu, group chatting, hingga mailing list. Biasanya yang menjadi masalah adalah ketika ada kegiatan berbagi pengetahuan melalui CoP, dokumen sebagai elemen vital tidak diperhatikan. Padahal dengan dokumen yang telah dipilah dan diberi makna lewat serangkaian diskusi itu, kemunculan pengetahuan baru dapat diharapkan.

Proses tersebut juga yang terjadi pada Program Vokasi UI. Banyak yang tidak menyadari dan mengetahui bahwa yang telah dilakukan selama ini adalah salah satu bentuk CoP. Pengetahuan dari satu staf pengajar yang dibagikan ke staf pengajar lain, meskipun hanya melalui media komunikasi baru berbasis teknologi informasi dan komunikasi sebenarnya adalah bagian dari memindahkan pengetahuan baik tacit ataupun eksplisit. Biasanya proses perpindahan itu bersifat alamiah dan tanpa sadar yang menerima pengetahuan pun tidak begitu peduli telah mendapatkan pengetahuan baru. Menariknya, keberadaan dokumen sebagai bukti pengaliran pengetahuan dari individu ke individu lainnya, juga tidak terlalu diperhatikan. Padahal, dokumen menjadi kunci dalam proses pembentukan pengetahuan baru. Apabila dokumen tertata dengan baik dan mudah diakses oleh semua anggota organisasi, organisasi dapat bekerja lebih cepat dan efisien. Mereka tidak perlu mengulang-ulang pekerjaan yang sama antar rumpun ilmu di Program Vokasi UI karena sudah ada model yang dapat digunakan ataupun diadopsi. Ketika dokumen sudah menjadi bagian tidak terpisahkan dari sistem berbagi pengetahuan maka efektivitas $\mathrm{CoP}$ sebagai sarana berbagi pengetahuan akan berjalan optimal.

Dengan kondisi tersebut, menarik untuk diteliti bagaimana persepsi staf pengajar tetap atau dosen tetap Program Vokasi UI dalam melihat CoP. Apakah proses CoP disadari di kalangan dosen tetap serta apakah ada manfaat yang dapat diperoleh ketika mereka melakukan CoP dalam berbagi pengetahuan. Ketika dokumen dari berbagi pengetahuan tersebut tertata dan dapat diakses dengan mudah, apakah mereka dapat memanfaatkan apa yang terdokumentasikan tersebut menjadi pengetahuan baru.

Dari studi awal yang dilakukan penulis, proses berbagi pengetahuan sebagai alternatif penciptaan inovasi baru ditemukan fakta bahwa berbagi pengetahuan di lingkungan staf pengajar tetap Vokasi UI belum berjalan secara struktural. Model yang ditawarkan dengan menciptakan knowledge manager ataupun knowledge centre sebagai pengelola pengetahuan masih sebatas gagasan. Tentu menjadi menarik bila praktek-praktek CoP sebagai awal dari bagian berbagi pengetahuan telah dilakukan. Meskipun persepsi bahwa $\mathrm{CoP}$ memungkinkan berbagi pengetahuan dapat terjadi belum menyentuh semua staf pengajar tetap Program Vokasi.

Dari penelitian ini dapat mengetahuai persepsi dosen tetap Program Vokasi Universitas Indonesia terhadap proses berbagi pengetahuan melalui $\mathrm{CoP}$ (Communities of Practice). Apakah persepsi yang ditemukan memiliki hubungan positif atau negatif, serta untuk membuktikan apakah dokumen menjadi faktor penting dalam 
pelaksanaan proses berbagi pengetahuan melalui CoP.

Sedangkan manfaat penelitian ini yakni memungkinkan proses berbagi pengetahuan di antara dosen tetap Program Vokasi Universitas Indonesia dapat dilakukan secara berkala dan berkelanjutan sehingga manfaat yang akan diterima organisasi juga lebih besar.

Organisasi yang dapat memanfaatkan proses berbagi pengetahuan di antara anggotanya akan memperoleh banyak manfaat karena pengetahuan akan terus berkembang dinamis, lintas bidang, dan selalu sejalan dengan tuntutan jaman. Lalu lintas pengetahuan antar bidang yang bergerak dinamis juga akan membawa organisasi lebih mampu beradaptasi dengan perubahan lingkungan yang semakin cepat.

\section{Metode Penelitian}

Penelitian ini adalah penelitian kuantitatif menggunakan metode penelitian survei. Dalam penelitian ini yang menjadi responden adalah semua dosen tetap Vokasi UI yang berjumlah 40 orang (seluruh populasi).
Model riset yang diajukan adalah modifikasi dari model riset Money dan Turner (2008) tentang manajemen pengetahuan (model penelitian. (model digambarkan dalam gambar 1).

Ada tiga konstruk yang diteliti yaitu persepsi terhadap CoP, persepsi terhadap berbagi pengetahuan, dan persepsi terhadap dokumen dalam berbagi pengetahuan melalui $\mathrm{CoP}$. Hipotesis riset yang akan diteliti adalah :

H1 : Persepsi dosen tetap terhadap proses berbagi pengetahuan dan $\mathrm{CoP}$ adalah positif

H2 : Persepsi dosen tetap terhadap berbagi pengetahuan/CoP dan dokumen adalah positif

H3 : Dokumen adalah faktor penting dari proses berbagi pengetahuan dan $\mathrm{CoP}$

Selanjutnya dilakukan survei terhadap dosen tetap vokasi UI dengan mengajukan 14 pertanyaan terkait dengan variabel yang akan diteliti serta mengajukan pertanyaan dengan jawaban singkat sebagai tambahan data. Langkah berikutnya adalah melakukan analisis data.

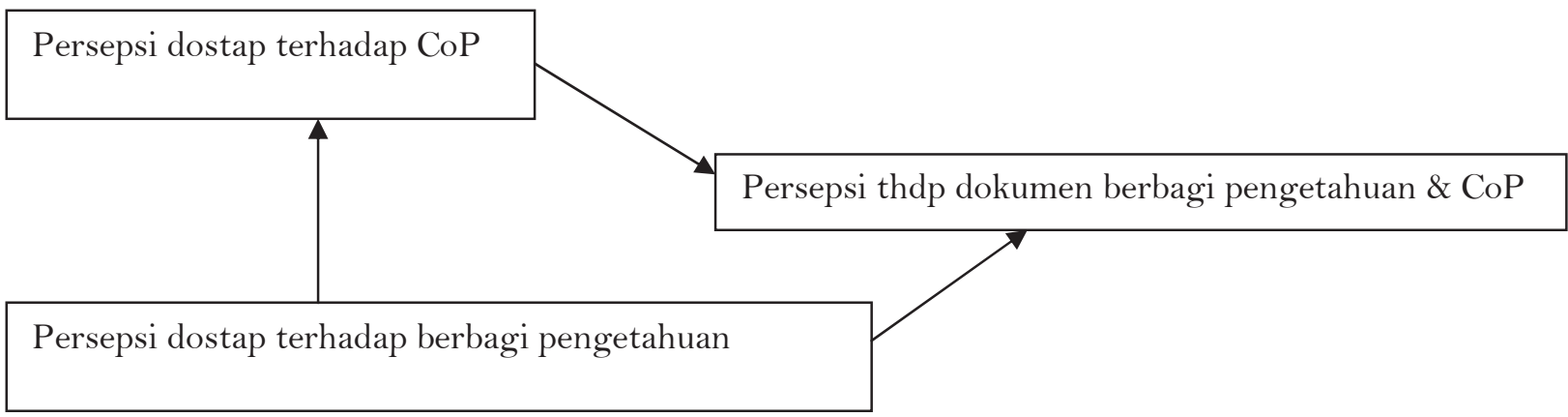

Gambar 1. Model riset penelitian 
Analisis yang dilakukan meliputi analisis realibilitas dan validitas, analisis korelasi, serta regresi untuk menguji hipotesis yang diajukan.

\section{HASIL DAN PEMBAHASAN}

Ada 33 dosen tetap yang menjadi responden dalam penelitian ini dari total 40 dosen tetap vokasi UI yang ada. Untuk mengolah data digunakan peranti lunak SPSS ver 17.0 untuk membantu perhitungan statistik.

\section{Uji Validitas}

Pengujian validitas digunakan untuk mengetahui apakan instrumen alat ukur dapat menjalankan fungsi ukurnya. Biasanya untuk mengukur validitas instrumen alat ukur digunakan analisis faktor atau menggunakan metode analisis korelasi. Berikut hasil pengujian validitas menggunakan analisis faktor. Butir-butir pertanyaan dalam penelitian ini dapat dikatakan valid karena memiliki factor loading > 0,4 sehingga benarbenar menjadi indikator pada masing-masing variabel.

Tabel 1. Cronbach's Alpha Reliability Coefficient

\begin{tabular}{|l|r|}
\hline Item & \\
\hline Berbagi pengetahuan & .785 \\
\hline CoP & .711 \\
\hline Dokumen & .757 \\
\hline
\end{tabular}

Sumber : Data Diolah

\section{Uji Reliabilitas}

Pengujian reliabilitas digunakan untuk mengetahui tingkat kestabilan suatu alat ukur. Hasilnya dapat dipercaya apabila digunakan dalam beberapa kali pengukuran terhadap kelompok subyek yang sama didapatkan hasil yang relatif sama. Dalam pengukuran menggunakan koefisien alfa suatu konstruk dapat dikatakan reliable bila nilai Cronbach Alpha > 0,7. Dari hasil pengujian reliabilitas pada penelitian ini didapatkan hasil $>0,7$ sehingga dapat dianggap reliable.

\section{Korelasi}

Uji korelasi digunakan untuk menguji ada tidaknya hubungan antar variabel satu dengan yang lain. Apabila kondisi hubungan antar variabel sudah diketahui adanya kecenderungan hubungan baik positif atau negatif antara dua variabel yang berhubungan. Pada penelitian ini digunakan uji bivariate correlation untuk menguji korelasi dua variabel dengan kondisi test of significance one-tailed (uji satu sisi). 


\begin{tabular}{|l|l|}
\hline & Component \\
\cline { 2 - 2 } & 1 \\
\hline Butir pertanyaan 1 BP & .410 \\
Butir pertanyaan 2 BP & .960 \\
Butir pertanyaan 3 BP & .978 \\
Butir pertanyaan 4 BP & .590 \\
Butir pertanyaan 5 BP & .413 \\
Butir pertanyaan 6 BP & .951 \\
\hline
\end{tabular}

\begin{tabular}{|l|c|}
\hline & Component \\
\cline { 2 - 2 } & 1 \\
\hline Butir1 pertanyaan CoP & .616 \\
Butir2 pertanyaan CoP & .917 \\
Butir3 pertanyaan CoP & .645 \\
Butir4 pertanyaan CoP & .901 \\
Butir5 pertanyaan CoP & .409 \\
\hline
\end{tabular}

Sumber : Data diolah

Sumber : Data diolah

Tabel 4 Factor loading Dokumen

\begin{tabular}{|c|c|}
\hline & Component \\
\cline { 2 - 2 } & 1 \\
\hline Butir1 pertanyaan dok & .970 \\
Butir2 pertanyaan dok & .434 \\
Butir3 pertanyaan dok & .970 \\
\hline
\end{tabular}

Sumber : Data diolah

Tabel 5. Matriks Korelasi Pengujian

\begin{tabular}{|c|c|c|c|}
\hline & Berbagi Pngthn & CoP & Dok \\
\hline BP & 1 & 0.559 & 0.828 \\
\hline CoP & 0.559 & 1 & 0.621 \\
\hline Dok & 0.828 & 0.621 & 1 \\
\hline
\end{tabular}

Sumber : Data diolah

Tabel 6. Analisis Regresi

\begin{tabular}{|l|l|l|l|l|}
\hline Model & $R$ & R Square & Adjusted R Square & $\begin{array}{l}\text { Std. Error of the } \\
\text { Estimate }\end{array}$ \\
\hline 1 & $.849^{\mathrm{a}}$ & .721 & .703 & 1.499 \\
\hline
\end{tabular}

a. Predictors: (Constant), Total CoP, Total B

Sumber : Data diolah

Dari hasil tersebut persepsi dosen tetap terhadap berbagi pengetahuan dan CoP menunjukkan korelasi positif. Dengan nilai korelasi 0.559 berarti ada hubungan signifikan antara keduanya dengan nilai signifikansi $>0.01$. Artinya $\mathrm{H} 1$ yang ditentukan dalam penelitian ini dapat diterima. 
Sedangkan pada $\mathrm{H} 2$ terdapat korelasi positif antara $\mathrm{CoP}$ dengan dokumen serta berbagi pengetahuan dan dokumen dengan nilai korelasi masing-masing 0.828 dan 0.621 yang berarti ada hubungan signifikan antara keduanya dengan signifikansi $>0,01$

Pada H3, untuk menguji apakah benar dokumen menjadi faktor penting dalam terlaksananya proses berbagi pengetahuan dan $\mathrm{CoP}$ digunakan analisis regresi dengan nilai $\mathrm{R}$ square mengukur seberapa besar kontribusi variabel independen (dokumen) dalam menjelaskan variabel dependen (berbagi pengetahuan dan $\mathrm{CoP}$ ). Nilai adjusted $\mathrm{R}$ square sebesar 0.702 berbarti peran variabel dokumen mampu menjelaskan variabel berbagi pengetahuan dan $\mathrm{CoP}$ sebesar 70,3\%. Jadi, pada penelitian ini H3 dapat diterima.

\section{PENUTUP}

\section{Simpulan}

Hasil dari penelitian persepsi dosen vokasi UI pada proses berbagi pengetahuan, $\mathrm{CoP}$, dan dokumen dapat disimpulkan bahwa persepsi dosen cenderung positif. Korelasi antar ketiga variabel ini terbukti positif dan menjawab hipotesis penelitian. Dari hasil tersebut dapat disimpulkan bahwa berbagi pengetahuan melalui CoP dapat digunakan sebagai salah satu alternatif dalam membentuk proses berbagi pengetahuan di program vokasi UI.

\section{Saran}

Dokumen menjadi unsur penting yang harus ada dalam proses berbagi pengetahuan melalui CoP. Dengan dokumen, proses penyimpanan dan penyebaran pengetahuan dapat berlangsung dengan baik. Pengetahuan baru sebagai hasil dari proses berbagi pengetahuan melalui CoP akan menjadi lebih terorganisir dan dapat diakses kembali dengan lebih mudah ketika dibutuhkan. Ketika proses berbagi pengetahuan dilakukan disarankan untuk menggunakan sarana dokumentasi yang dapat diakses oleh semua anggota organisasi dengan mudah. Penggunaan teknologi informasi dalam dokumentasi dapat menjadi solusi yang diharapkan dengan tetap mempertimbangkan hasil-hasil berbagi pengetahuan dalam bentuk dokumen fisik. Keterbatasan dari penelitian ini adalah cakupan penelitian hanya terbatas membidik organisasi dosen tetap Program Vokasi Universitas Indonesia. Tentu hasil ini tidak dapat diterapkan di organisasi lain dengan kompleksitas maupun struktur organisasi yang berbeda. 


\section{DAFTAR PUSTAKA}

Money, William dan Turner Arch (2008). Assessing Knowledge Management System User Acceptance with the Technology Acceptance Model In Jennex, Murray E, (Ed) Knowledge Management : Concept, Methodologies, Tools, and Application. (vol. 4, pp.1649-1667) Hershey : Information Science Reference.

Neuman, Lawrence W. (2000) Social Research Methods : Qualitative and Quantitative Approach. Massachusetts : Pearson Education Company.

Nonaka, I. \& Takeuchi, H. (1995). The Knowledge- Creating Company: How Japanese Companies Create the Dynamics Innovation New York: Oxford University Press.

Paquette, Scott (2008). Communities of Practices as Facilitators of Knowledge Exchange. In Jennex,

Murray E, (Ed) Knowledge Management : Concept, Methodologies, Tools, and Application. (vol. 4, pp.1683-1689) Hershey : Information Science Reference.

Setiarso, Bambang., et.al (2009). Penerapan Knowledge Manajemen Pada Organisasi. Yogyakarta : Graha Ilmu.

Singarimbun, Masri dan Effendi, Sofian (1989). Metode Penelitian Survei. Jakarta : LP3ES

Wenger, E. (1999). Communities of Practice: Learning, Meaning, and Identity. Cambridge : Cambridge University Press.

Wenger,E., McDermott,R., dan Snyder,W.M. (2002). Cultivating communities of practice Boston: Harvard Business School Press 